\title{
KREATIVITAS DIDIK BAMBANG WAHYUDI DALAM KARYA TARI ANOMAN CAKIL
}

\author{
Denny Rostyana Putri \\ Institut Seni Indonesia (ISI) Surakarta \\ Jalan Ki Hajar Dewantara No. 19 kentingan, Jebres, Surakarta 57126 \\ Karyono \\ Institut Seni Indonesia (ISI) Surakarta
}

\begin{abstract}
Abstrak
This thesis is titled by the Creativity of Didik Bambang Wahyudi in Anoman Cakil dance to uncover the creativity of Didik Bambang Wahyudi by describing and explaining: (1) The form of Anoman Cakil dance and (2) Didik Bambang Wahyudi's creativity in the works of Anoman Cakil dance. Both issues were examined using the concept of the show form by Maryono which reveals verbal and non-verbal components. To uncover the creativity of Didik Bambang Wahyudi in the work of Anoman Cakil dance is using the theory of Rhodes cited by Utami Munandar that creativity there are four elements in it, namely person, press, proscess and product. Anoman Cakil dance composed by Didik Bambang Wahyudi told about the battle between two characters that have different character of Anoman and Cakil. Anoman Cakil dance is a dance work born from the interpretation of Didik Bambang Wahyudi. Harmony between the person and the creative process, as well as the ability to implement a story where Anoman essentially never met Cakil, but it is not impossible for Anoman to meet Cakil on a journey.
\end{abstract}

Keywords: creativity, form, Anoman Cakil dance.

\section{PENDAHULUAN}

Tari Anoman Cakil disusun oleh Didik Bambang Wahyudi dan Silvester Pamadi pada tahun 1987. Karya ini disusun guna memenuhi materi pembelajaran dan ujian tugas akhir minat kepenarian di STSI Surakarta atau Institut Seni Indonesia (ISI) Surakarta. Tari Anoman Cakil merupakan karya kolaborasi yang disusun oleh Didik Bambang Wahyudi dan Silvester Pamardi. Berdasarkan kesepakatan antara kedua koreografer, Tari Anoman Cakil diatasnamakan sebagai karya Didik
Bambang Wahyudi (Didik Bambang Wahyudi, wawancara 17 Oktober 2019).

Tari Anoman Cakil merupaka tari gagah gaya Surakarta jenis tari wireng pethilan. Wireng pethilan menggunakan unsur cerita yang dipungut dari cerita tertentu. Kata pethilan mempunyai arti memetik. Maksudnya adalah memetik sebagian dari sebuah cerita (Pamardi, 2017: 6). Tari ini menceritakan tentang peperangan antara dua tokoh yang memiliki perbedaan karakter yaitu Anoman dan Cakil. Cakil merupakan abdi kinasih Rahwana dan 
juga sosok prajurit yang menjadi halangan atau rintangan yang dihadapi oleh Anoman. Cakil mempunyai ciri rahang bawah lebih menjorok ke depan dibandnig rahang atas.

Ide untuk menyusun tari Anoman Cakil didasarkan pada keinginan untuk menggarap dua tokoh dengan karakter yang berbeda, namun memiliki teknik gerak kaki yang serupa. Anoman dengan karakter gagah anteb namun memiliki teknik gerak kaki yang ringan (trincing), sedangkan Cakil memiliki karakter gagah bregas namunjuga memiliki teknik gerak yang ringan (trincing) (Didik Bambang Wahyudi, 2011: 143).

Tari Anoman Cakil mengungkapkan cerita Ramayana dalam episode Anoman Duta, yang di dalamnya menceritakan peperangan antara Anoman dan Cakil. Dalam sejarahnya, Anoman tidak pernah bertemu Cakil. Tetapi dalam konteks, Cakil tersebut adalah Kalamarica yang diinterpretasikan sebagai pasukan sandi Rahwana. Anoman dalam perjalananya dari Ayodya menuju Alengka melewati banyak rintangan termasuk Kalamarica. Kalamarica merupakan prajurit terdekat Rahwana yang sakti dan bisa berubah menjadi Kidang. Tokoh Cakil adalah tokoh fiktif yang sebenarnya menggambarkan tentang nafsu, ketika dikaitkan dengan Kalamarica, sosok cakil itu divisualisasikan atau ditokohkan sehingga perang yang terjadi adalah perang fisik. Anoman Cakil bisa kedunya, yaitu Anoman yang memerangi hatinya sendiri dan dalam konteks, Anoman memerangi Kalamarica (Didik Bambang Wahyudi, wawancara 17 Oktober 2019).

Rias yang digunakan untuk tokoh Anoman yaitu menggunakan rias karakter kera. Untuk tokoh Cakil menggunakan rias karakter khusus Cakil serta menggunakan busana layaknya wayang orang. Musik tari pada tari Anoman Cakil yaitu menggunakan gamelan jawa lengkap.

\section{BENTUK TARI ANOMAN CAKIL}

Bentuk adalah perpaduan dari beberapa unsur atau komponen yang bersifat fisik, saling mengkait dan terintegrasi dalam suatu kesatuan. Sebagai bentuk seni yang dipertunjukan atau ditonton masyarakat, tari dapat dipahami sebagai bentuk yang memiliki unsur- unsur atau komponenkomponen dasar yang secara visual dapat ditangkap dengan indera manusia (Maryono, 2015: 24).

Untuk membahas bentuk pertunjukan Tari Anoman Cakil menggunakan konsep Maryono yaitu bentuk tari secara garis besar terdiri dari komponen-komponen dasar yang dapat dibedakan menjadi dua, yaitu: a) komponen verbal dan b) komponen nonvebal (Maryono, 2015: 24). Komponen verbal berfungsi sebagai penyampai isi atau makna yang menggunakan lagu, ritme dan bahasa yang indah. Dalam buku Pragmatik Genre Tari Pasihan Gaya Surakarta terdapat pendapat Kreidler yang mengkategorisasikan tindak tutur menjadi tujuh jenis, seperti yang dikemukakan dalam bukunya Introducing English Samantics (1998:183-194) yaitu: Asertif, Performatif, Verdiktif, Ekspresif, Direktif, Komisif dan Patik (Maryono, 2010:36-38). Selain komponen verbal, terdapat pula komponen nonverbal, komponen nonverbal menurut Maryono yaitu:

Komponen nonverbal merupakan jenis-jenis komponen atau unsur yang berbentuk nonkebahasaan. Bentuk 
komponen-komponen nonverbal dalam tari merupakan bentuk yang secara visual dapatditangkap dengan indera manusia. Jenis-jenis komponen atau unsur tari yang berbentuk nonverbal atau nonkebahasaan terdiri dari: 1) tema, 2) Gerak, 3) penari, 4) ekspresi wajah/polatan, 5) rias, 6) busana, 7) iringan, 8) panggung, 10) properti, dan 11) pencahayaan.

\section{KOMPONEN VERBAL}

Pada kajian ini lebih mengarah pada komponen verbal pada tari Anoman Cakil, dalam buku yang berjudul Analisa Tari, Maryono mengatakan:

Komponen verbal adalah jenis-jenis unsur atau eleman yang berbentuk kebahasaan. Dalam seni pertunjukan komponen verbal adalah komponen yang berfungsi untuk penunjuk isi atau pesan makna dan penyampai isi atau pesan makna" (2015: 25).

Maryono mengutip pendapat Kreidler yaitu dalam perkembanganya Kreidler mengkatagorisasikan tindak tutur menjadi tujuh jenis, seperti yang dikemukakan dalam bukunya Introducing English Semantics (1998: 183-194) yaitu: Asertif, Performatif, Verdiktif, Ekspresif, Direktif, Komisif dan Patik (Maryono, 2010:36-38) (Maryono, 2010: 36).

Komponen verbal yang terdapat pada Tari Anoman Cakil yaitu sastra tembang Ada-ada laras slendro pathet manyuro. Merujuk pada fungsinya, ada- ada laras slendro pathet manyuro sebagai sarana informasi kepada penonton dan sebagai penggambaran suasana dalam sajian Tari Anoman Cakil.
Tabel 1. Jenis-jenis Tindak Tutur (TT) yang terdapat pada teks Ada-ada laras slendro pathet manyuro

\begin{tabular}{|c|c|c|c|c|}
\hline No & $\begin{array}{c}\text { Vokalis } \\
\text { (pa) }\end{array}$ & $\begin{array}{c}\text { Teks Verbal Ada-ada laras } \\
\text { slendro manyuro }\end{array}$ & $\begin{array}{c}\text { Jenis- } \\
\text { jenis } \\
\text { TT }\end{array}$ & Pemarkah \\
\hline 1. & \multirow{5}{*}{$\begin{array}{l}\text { Vokalis } \\
\text { (pa) }\end{array}$} & $\begin{array}{l}\text { Ridhu mawur mangawu } \\
\text { awur wurahan }\end{array}$ & \multirow{5}{*}{ Asertif } & Mangawu awur wurahan \\
\hline 2. & & Tengaraning ajurit, $\mathrm{o}$ & & Tengaraning \\
\hline 3. & & Gong maguru gangsa & & Gong \\
\hline 4. & & Teteg kadya butula & & Teteg kadya butula \\
\hline 5. & & Wor panjriting turang gesthi, o & & Panjriting turang gaesthi \\
\hline
\end{tabular}

\section{a. Konteks}

Konteks dipahami sebagai lingkungan yang melingkupi yang memungkinkan peserta tutur berintaraksi dan yang membantu mereka memahamiungkapan- ungkapan kebahasaan yang mereka gunakan dalam suatu proses komunikasi (Maryono, 2015:75).

Berdasarkan teks ada-ada laras slendro pathet manyuro yang telah diterjemahkan oleh Wahyu Santoso Prabowo, pada konteks terdapat peserta tutur: vokal pria, tema: peprangan, tujuan: Bentuk penggambaran dari suasana peperangan yang menegangkan. Peperangan yang terjadi antara Anoman dan Cakil, dimana saat dalam perjalanan Anoman mencari Dewi Sinta ke Alengka, kemudian dihadang oleh abdi kinasih Rahwana yaitu Cakil. Status sosial: Anoman adalah Senopati utusan Ramawijaya. Cakil adalah prajurit sandi dari Rahwana, tempat kejadian: Negara Alengka, situasi tutur: tidak formal, gerak: Anoman dengan karakter gagah anteb dan Cakil dengan karakter gagah bregas. Anoman masuk menuju gawang supana dengan gerak loncat menjangan, tanjak tancep kiri, ulap- ulap kambeng, mere, nggelebak, tanjak 
tancep kiri. Cakil masuk menuju gawang supana dengan gerak loncat, sempok, tanjak kiri, ngelit, nebak, ngglebak menghadap kedepan, tanjak tancep kiri, polatan: Polatan Anoman tampak tenang. Cakil tampak congkak atau kemaki, pola lantai: didominasi garis lurus, dan iringan: ada-ada laras slendro manyuro. Adapun implikatur yaitu:

a. Implikatur

Implikatur menurut Maryono dalam bukunya yang berjudul Pragmatik Genre Tari Pasihan Gaya Surakarta mengatakan bahwa implikatur adalah makna yang disiratkan dalam sebuah percakapan (Maryono, 2010:46). Makna yang terdapat pada satra tembang ada-ada laras slendro manyuro adalah penggambaran dari suasana peperangan yang terjadi antara Anoman dan Cakil.

\section{KOMPONEN NON VERBAL}

Komponen nonverbal merupakan jenis-jenis komponen atau unsur yang berbentuk nonkebahasaan. Bentuk komponen-komponen nonverbal dalam tari merupakan bentuk yang secara visual dapat ditangkap dengan indera manusia. Jenis-jenis nonkebahasaan terdiri dari: 1) tema, 2) gerak, 3) penari, 4) ekspresi wajah/polatan, 5) rias, 6) busana, 7) iringan, 8) panggung, 9) properti 10) pencahayaan" (Maryono, 2015: 52).

\section{Tema}

Tema dapat ditarik dari sebuah peristiwa atau cerita, yang selanjutnya dijabarkan menjadi alur cerita sebagai kerangka sebuah garapan (Maryono, 2010: 53).Tari Anoman Cakil menggunakan tema peperangan yang mengangkat cerita Ramayana pada episode Anoman Duta.

\section{Gerak}

Kehadiran gerak dalam tari merupakan media baku yang digunakan sebagai alat komunikasi untuk menyampaikan pesan seniman. Secara garis besar, Maryono membagi gerak menjadi dua kelompok yaitu gerak representatif atau gerak murni dan gerak presentatif atau penghadir (Maryono, 2015: 54).

Tabel3. Jenis-jenis gerak presentatif tokoh Anoman pada Ada-ada

\begin{tabular}{|c|c|c|c|c|}
\hline \multicolumn{2}{|c|}{ Adegan } & \multirow{2}{*}{$\begin{array}{l}\text { Nama tokoh } \\
\text { Anoman }\end{array}$} & \multirow{2}{*}{ Jenis gerak } & \multirow{2}{*}{ Keterangan } \\
\hline No & \multirow{7}{*}{ Ada- ada } & & & \\
\hline 1. & & Tanjak tancep & \multirow{6}{*}{ Presentatif } & Kesan gagah \\
\hline 2. & & Mere & & Kesan terkejut \\
\hline 3. & & Tanjak Tancep & & Kesan gagah \\
\hline 4. & & Ngelit & & Kesan mengintai \\
\hline 5. & & Hoyog kiri kambeng & & Kesan anteb \\
\hline 6. & & Tanjak kiri & & Kesan gagah \\
\hline
\end{tabular}

Tabel 4. Jenis-jenis gerak representatif tokoh Anoman pada ada-ada

\begin{tabular}{|c|c|c|c|c|}
\hline \multicolumn{2}{|c|}{ Adegan } & Nama tokoh & \multirow{2}{*}{ Jenis gerak } & \multirow{2}{*}{ Keterangan } \\
\hline No. & \multirow{5}{*}{$\begin{array}{l}\text { Ada- } \\
\text { ada }\end{array}$} & Anoman & & \\
\hline 1. & & Loncat menjangan & \multirow{4}{*}{ Representatif } & Stilisasi gerak rusa berlari \\
\hline 2. & & Ulap-ulap kambeng & & Stilisasi orang melihat \\
\hline 3. & & Mundur kanan & & Stilisasi orang mundur \\
\hline 4. & & Junjungan kiri & & $\begin{array}{l}\text { Stilisasi orang mengangkat kaki } \\
\text { kiri }\end{array}$ \\
\hline
\end{tabular}

Tabel 5. Jenis-jenis presentatif tokoh Cakil pada ada-ada 
Tabel 6. Jenis-jenis gerak representatif tokoh Cakil pada ada-ada

\begin{tabular}{|c|c|c|c|c|}
\hline \multicolumn{2}{|c|}{ Adegan } & Nama tokoh & \multirow{2}{*}{ Jenis gerak } & \multirow{2}{*}{ Keterangan } \\
\hline No. & \multirow{11}{*}{$\begin{array}{l}\text { Maju } \\
\text { beksan }\end{array}$} & Cakil & & \\
\hline 1. & & Loncat & \multirow{10}{*}{ Representatif } & Stilisasi gerak orang meloncat \\
\hline 2. & & Sempok & & $\begin{array}{l}\text { Stilisasi gerak orang duduk } \\
\text { simpuh }\end{array}$ \\
\hline 3. & & Nebak & & Stilisasi gerak orang memukul \\
\hline 4. & & Ngglebak & & $\begin{array}{l}\text { Stilisasi gerak orang membalik } \\
\text { badan }\end{array}$ \\
\hline 5. & & Ulat-ulatan & & Stilisasi orang melihat \\
\hline 6. & & Ngglebak & & Stilisasi orang membalik badan \\
\hline 7. & & Grayangan & & $\begin{array}{l}\text { Stilisasi orang ketika akan } \\
\text { menyentuh }\end{array}$ \\
\hline 8. & & Mundur & & Stilisasi orang mundur \\
\hline 9. & & Loncat & & Stilisasi orang meloncat \\
\hline 10. & & Ngglebak & & Stilisasi orang membalik badan \\
\hline
\end{tabular}

Tabel 7. Jenis-jenis gerak presentatif tokoh Anoman pada maju beksan

\begin{tabular}{|c|c|c|c|c|}
\hline \multicolumn{2}{|c|}{ Adegan } & Nama tokoh & \multirow{2}{*}{ Jenis gerak } & \multirow{2}{*}{ Keterangan } \\
\hline No. & \multirow{11}{*}{$\begin{array}{l}\text { Maju } \\
\text { Beksan }\end{array}$} & Anoman & & \\
\hline 1. & & Tanjak tancep & \multirow{10}{*}{ Presentatif } & Kesan gagah dan tenang \\
\hline 2. & & Sabetan & & Gerak penghubung atau sekaran \\
\hline 3. & & Ombak banyu & & Gerak penghubung atau sekaran \\
\hline 4. & & Ngancap & & Kesan waspada \\
\hline 5. & & Ngelit & & Kesan mengintai \\
\hline 6. & & Tanjak & & Kesan gagah \\
\hline 7. & & Ngancap & & Kesan waspada \\
\hline 8. & & Tanjak & & Kesan gagah \\
\hline 9. & & Ngelit & & Kesan mengintai \\
\hline 10. & & Tanjak & & Kesan anteb \\
\hline
\end{tabular}

Tabel 8. Jenis-jenis gerak representatif tokoh Anoman pada maju beksan

\begin{tabular}{|c|c|c|c|c|}
\hline \multicolumn{2}{|c|}{ Adegan } & \multirow{2}{*}{\begin{tabular}{|l|} 
Nama tokoh \\
Anoman \\
\end{tabular}} & \multirow{2}{*}{ Jenis gerak } & \multirow{2}{*}{ Keterangan } \\
\hline No. & \multirow{9}{*}{$\begin{array}{l}\text { Maju } \\
\text { beksan }\end{array}$} & & & \\
\hline 1. & & Sembahan & \multirow{8}{*}{ Representatif } & Stilisasi gerak orang menyembah \\
\hline 2. & & Lumaksono & & Stilisasi gerak orang berjalan \\
\hline 3. & & Ngancap & & Stilisasi orang membalik badan \\
\hline 4. & & Mundur & & Stilisasi gerak orang mundur \\
\hline 5. & & Endo & & Stilisasi gerak orang menghindar \\
\hline 6. & & Mutar & & Stilisasi gerak orang memutar \\
\hline 7. & & Jeblosan & & \begin{tabular}{|lll}
$\begin{array}{l}\text { Stilisasi gerak orang salin } \\
\text { menyerang }\end{array}$ & & \\
\end{tabular} \\
\hline 8. & & Loncat & & Stilisasi gerak kera meloncat \\
\hline
\end{tabular}

Tabel 9. Jenis-jenis gerak presentatif tokoh Cakil pada maju beksan

\begin{tabular}{|c|c|c|c|c|}
\hline \multicolumn{2}{|c|}{ Adegan } & Nama tokoh & \multirow{2}{*}{ Jenis gerak } & \multirow{2}{*}{ Keterangan } \\
\hline No. & \multirow{11}{*}{$\begin{array}{l}\text { Maju } \\
\text { beksan }\end{array}$} & Cakil & & \\
\hline 1. & & Tanjak tancep & \multirow{10}{*}{ Presentatif } & Kesan gagah \\
\hline 2. & & Sabetan & & Gerak penghubun/sekaran tari \\
\hline 3. & & Ombak banyu & & Gerak penghubung/ sekaran tari \\
\hline 4. & & Ngancap & & Kesan siaga \\
\hline 5. & & Ngelit & & Kesan mengintai \\
\hline 6. & & Tanjak & & Kesan gagah \\
\hline 7. & & Sawuran & & Gerak penghubung/sekaran tari \\
\hline 8. & & Tanjak & & Kesan gagah \\
\hline 9. & & Ngancap & & Kesan siaga \\
\hline 10. & & Ngelit & & Kesan mengintai \\
\hline
\end{tabular}

Tabel 10. Jenis-jenis gerak representatif tokoh Cakil pada maju beksan

\begin{tabular}{|c|c|c|c|c|}
\hline \multicolumn{2}{|c|}{ Adegan } & Nama tokoh & \multirow{2}{*}{ Jenis gerak } & \multirow{2}{*}{ Keterangan } \\
\hline No. & \multirow{11}{*}{$\begin{array}{l}\text { Maju } \\
\text { beksan }\end{array}$} & Cakil & & \\
\hline 1. & & Sembahan & \multirow{10}{*}{ Representatif } & Stilisasi gerak orang menyembah \\
\hline 2. & & Lumaksono & & Stilisasi gerak orang berjalan \\
\hline 2. & & $\begin{array}{l}\text { Loncat menuju } \\
\text { gawang pojok depan } \\
\text { kiri }\end{array}$ & & $\begin{array}{l}\text { Stilisasi gerak orang meloncat } \\
\text { menuju arah pojok depan bagian kiri }\end{array}$ \\
\hline 3. & & Ngglebak & & $\begin{array}{l}\text { Stilisasi gerak orang membalik } \\
\text { badan }\end{array}$ \\
\hline 4. & & Mundur & & Stilisasi gerak orang mundur \\
\hline 5. & & Ngglebak & & $\begin{array}{l}\text { Stilisasi gerak orang membalik } \\
\text { badan }\end{array}$ \\
\hline 6. & & Jeblosan & & $\begin{array}{l}\text { Stilisasi gerak orang saling } \\
\text { menyerang }\end{array}$ \\
\hline 7. & & Ngglebak & & $\begin{array}{l}\text { Stilisasi gerak orang membalik } \\
\text { badan }\end{array}$ \\
\hline 8. & & Grayangan & & $\begin{array}{l}\text { Stilisasi gerak orang ketika akan } \\
\text { menyentuh }\end{array}$ \\
\hline 10. & & Mundur & & Stilisasi gerak orang mundur \\
\hline
\end{tabular}

Tabel 11. Jenis-jenis gerak presentatif tokoh Anoman pada beksan

\begin{tabular}{|c|c|c|c|c|}
\hline \multicolumn{2}{|c|}{ Adegan } & Nama tokoh & \multirow{2}{*}{ Jenis gerak } & \multirow{2}{*}{ Keterangan } \\
\hline No. & \multirow{14}{*}{ Beksan } & Anoman & & \\
\hline 1. & & Sabetan & \multirow{13}{*}{ Presentatif } & \multirow{3}{*}{ 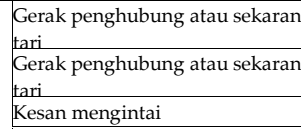 } \\
\hline 2. & & Sekaran kambeng & & \\
\hline 3. & & Ngelit & & \\
\hline 4. & & Tanjak & & Kesan gagah anteb \\
\hline 5. & & Sabetan srimpet & & Gerak penghubung atau sekaran \\
\hline 6. & & Tanjak & & Kesan tenang \\
\hline 7. & & \begin{tabular}{|ll} 
Sekaran & ogek \\
lambung
\end{tabular} & & $\begin{array}{l}\text { Gerak penghubung atau sekaran } \\
\text { tari }\end{array}$ \\
\hline 8. & & Tanjak & & Kesan tenang \\
\hline 9. & & $\begin{array}{l}\text { Sekaran ogek } \\
\text { lambung }\end{array}$ & & $\begin{array}{l}\text { Gerak penghubung atau sekaran } \\
\text { tari }\end{array}$ \\
\hline 10. & & Stregel & & Kesan terkejut \\
\hline 11. & & Tanjak gebes & & Kesan tenang \\
\hline 12. & & Ngelit & & Kesan mengintai \\
\hline 13. & & Tanjak gebes & & Kesan tenang \\
\hline
\end{tabular}

Tabel 12. Jenis-jenis gerak representatif tokoh Anoman pada beksan

\begin{tabular}{|c|c|c|c|c|}
\hline \multicolumn{2}{|c|}{ Adegan } & Nama tokoh & \multirow{2}{*}{ Jenis gerak } & \multirow{2}{*}{$\begin{array}{c}\text { Keteran } \\
\text { gan }\end{array}$} \\
\hline No. & \multirow{7}{*}{ Beksan } & Anoman & & \\
\hline 1. & & Loncat & \multirow{6}{*}{$\begin{array}{l}\text { Representat } \\
\text { if }\end{array}$} & Stilisasi gerak orang meloncat \\
\hline 2. & & Srimpet & & $\begin{array}{l}\text { Stilisasi gerak orang berpindah } \\
\text { tempat }\end{array}$ \\
\hline 3. & & Junjungan kanan & & $\begin{array}{l}\text { Stilisasi gerak orang mengangkat } \\
\text { kaki kanan }\end{array}$ \\
\hline 4. & & Loncat & & Stilisasi gerak orang meloncat \\
\hline 5. & & Menek & & Stilisasi gerak kera memanjat \\
\hline 6. & & Junjungan kanan & & $\begin{array}{l}\text { Stilisasi gerak orang mengangkat } \\
\text { kaki kanan }\end{array}$ \\
\hline 7. & & Loncat & & Stilisasi gerak orang meloncat \\
\hline 8. & & Ulap-ulap kambeng & & Stilisasi gerak orang melihat \\
\hline 9. & & Ngglebak & & $\begin{array}{l}\text { Stilisasi gerak orang membalik } \\
\text { badan }\end{array}$ \\
\hline 10. & & Grayangan & & $\begin{array}{l}\text { Stilisasi gerak orang ketika akan } \\
\text { menventuh }\end{array}$ \\
\hline 11. & & Onclangan & & Stilisasi gerak orang berlari \\
\hline
\end{tabular}




\begin{tabular}{|c|c|c|c|}
\hline 12. & Prenjak tinaji & \multirow{12}{*}{ Representatif } & Stilisasi gerak kaki burung prenjak \\
\hline 13. & Loncat & & Stilisasi gerak orang meloncat \\
\hline 14. & Ngglebak & & Stilisasi gerak orang membalik \\
\hline 15. & Menyerang & & Stilisasi gerang orang menyerang \\
\hline 16. & Ngglebak & & $\begin{array}{l}\text { Stilisasi gerak orang membalik } \\
\text { badan }\end{array}$ \\
\hline 17. & Ngglebak & & $\begin{array}{l}\text { Stilisasi gerak orang membalik } \\
\text { badan }\end{array}$ \\
\hline 18. & Endo & & Stilisasi gerak orang menghindar \\
\hline 19. & Menyerang & & Stilisasi gerak orang menyerang \\
\hline 20. & Junjungan kiri & & Stilisasi gerak orang mengangkat \\
\hline 21. & Lumaksono & & Stilisasi gerak orang berjalan \\
\hline 22. & Onclangan & & Stilisasi gerak orang berlari \\
\hline 23. & Menyerang & & Stilisasi gerak orang menyerang \\
\hline
\end{tabular}

Tabel 13. Jenis-jenis gerak presentatif tokoh Cakil pada beksan

\begin{tabular}{|c|c|c|c|c|}
\hline \multicolumn{2}{|c|}{ Adegan } & \multirow{2}{*}{\begin{tabular}{|l} 
Nama tokoh \\
Cakil \\
\end{tabular}} & \multirow{2}{*}{ Jenis gerak } & \multirow{2}{*}{ Keterangan } \\
\hline No. & \multirow{21}{*}{ Beksan } & & & \\
\hline 1. & & Tajak & \multirow{20}{*}{ Presentatif } & Kesan gagah \\
\hline 2. & & Sabetan & & Gerak penghubung/sekaran tari \\
\hline 3. & & Sekaran bapang & & Gerak penghubung/sekaran tari \\
\hline 4. & & Ngelit & & Kesan ngglece \\
\hline 5. & & Tanjak & & Kesan gagah \\
\hline 6. & & Tanjak glebakan & & Kesan waspada \\
\hline 7. & & Tanjak gebes & & Kesan tenang \\
\hline 8. & & Ngelit & & Kesan ngglece \\
\hline 9. & & Cekotan & & Kesan ngglece \\
\hline 10. & & Mbandul & & Gerak penghubung/ sekaran tari \\
\hline 11. & & Tanjak gebes & & Kesan tenang \\
\hline 12. & & Grayangan & & Kesan sombong \\
\hline 13. & & Sekaran ogek & & Gerak penghubung/sekaran tari \\
\hline 14. & & Tanjak & & Kesan gagah \\
\hline 15. & & Ukur dedeg & & Kesan sombong \\
\hline 16. & & Cekotan & & Kesan ngglece \\
\hline 17. & & Tanjak gebes & & Kesan siaga \\
\hline 18. & & Balangan & & Kesan siaga \\
\hline 19. & & Cekotan & & Kesan ngglece \\
\hline 20. & & Tanjak & & Kesan gagah \\
\hline
\end{tabular}

Tabel 14. Jenis-jenis gerak representatif tokoh Cakil pda beksan

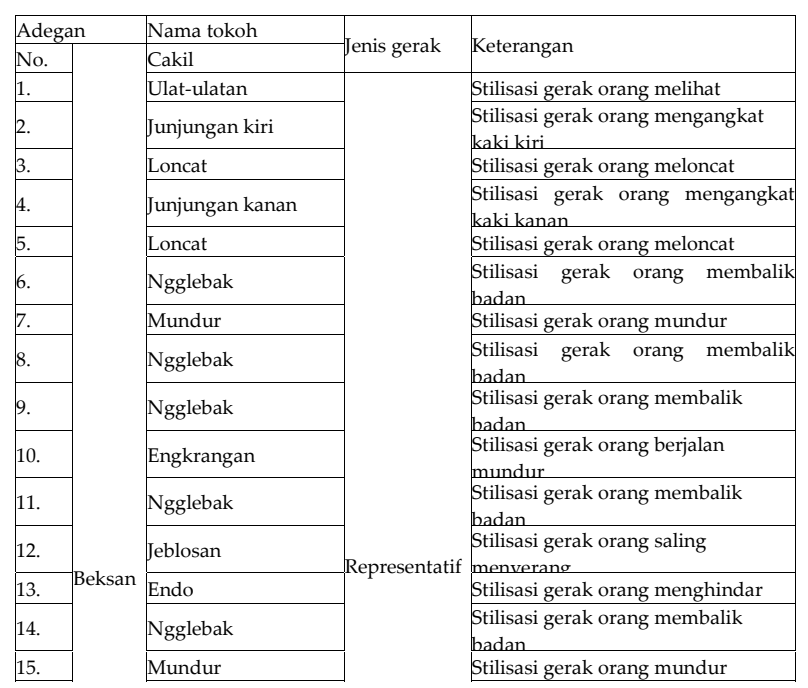

\begin{tabular}{|c|c|c|}
\hline 16. & Ngguyu & \multirow{2}{*}{$\begin{array}{l}\text { Stilisasi gerak orang tertawa } \\
\begin{array}{l}\text { Stilisasi gerak orang membalik } \\
\text { badan }\end{array}\end{array}$} \\
\hline 17. & Ngglebak & \\
\hline 18. & Nebak & Stilisasi gerak orang memukul \\
\hline 19. & Mundur & Stilisasi gerak orang mundur \\
\hline 20. & Ngglebak & Stilisasi gerak orang membalik bdan \\
\hline 21. & Ngglebak & \multirow{4}{*}{$\begin{array}{l}\begin{array}{l}\text { Stilisasi gerak orang membalik } \\
\text { badan } \\
\text { Stilisasi gerak orang mengambil } \\
\text { sesuatu } \\
\text { Stilisasi gerak orang membalik } \\
\text { badan } \\
\text { Stilisasi gerak orang berjalan } \\
\text { mundur }\end{array} \\
\end{array}$} \\
\hline 22. & Sawuran & \\
\hline 23. & Ngglebak & \\
\hline 24. & Mundur & \\
\hline
\end{tabular}

Tabel 15. Jenis-jenis gerak presentatif tokoh Anoman pada perang

\begin{tabular}{|c|c|c|c|c|}
\hline \multicolumn{2}{|c|}{ Adegan } & Nama tokoh & \multirow{2}{*}{ Jenis gerak } & \multirow{2}{*}{$\begin{array}{c}\text { Keteran } \\
\text { gan }\end{array}$} \\
\hline No. & \multirow{5}{*}{ Perang } & Anoman & & \\
\hline 1. & & Capengan & \multirow{4}{*}{ Presentatif } & Gerak penghubung atau sekaran \\
\hline 2. & & Ngancap & & Kesan waspada \\
\hline 3. & & Tanjak & & Kesan gagah \\
\hline 4. & & Ngelit & & Kesan $n$ gglece \\
\hline
\end{tabular}

\section{Tabel 16. Jenis-jenis gerak representatif} tokoh Anoman pada perang

\begin{tabular}{|c|c|c|c|c|}
\hline \multicolumn{2}{|c|}{ Adegan } & \multirow{2}{*}{\begin{tabular}{|l|} 
Nama tokoh \\
Anoman
\end{tabular}} & \multirow{2}{*}{ Jenis gerak } & \multirow{2}{*}{ Keterangan } \\
\hline No. & \multirow{31}{*}{ Perang } & & & \\
\hline 1. & & Eret-eretan & \multirow{30}{*}{ (1) } & \multirow{8}{*}{\begin{tabular}{|l|} 
Stilisasi gerak orang saling mengejar \\
Stilisasi gerak orang menghindar \\
Stilisasi gerak orang menangkis \\
Stilisasi gerak orang menyerang \\
Stilisasi gerak orang saling \\
memukul \\
Stilisasi gerak orang mloncat \\
Stilisasi gerak orang membalikan \\
badan \\
Menirukan sikap gerak kera
\end{tabular}} \\
\hline 2. & & Endo & & \\
\hline 3. & & Tangkis & & \\
\hline 4. & & Menyerang & & \\
\hline 5. & & Gapruk & & \\
\hline 6. & & Loncat & & \\
\hline 7. & & Ngglebak & & \\
\hline 8. & & Kethekan & & \\
\hline 9. & & Perangan 1 & & \multirow{4}{*}{\begin{tabular}{|l|} 
Stilisasi gerak orang berperang \\
Stilisasi gerak orang melihat \\
Stilisasi gerak orang berperang \\
$\begin{array}{l}\text { Stilisasi gerak orang berguling ke } \\
\text { arah depan }\end{array}$ \\
\end{tabular}} \\
\hline 10. & & Ulap-ulap kambeng & & \\
\hline 11. & & Perangan 2 & & \\
\hline 12. & & Berguling ke depan & & \\
\hline 13. & & Prenjak tinaji & & Stilisasi gerakkaki burung prenjak \\
\hline 14. & & Srisig & & \multirow{2}{*}{\begin{tabular}{|l} 
Stilisasi gerak orang berlari \\
Stilisasi gerak orang berjalan \\
\end{tabular}} \\
\hline 15. & & Lumaksono & & \\
\hline 16. & & Gapruk & & \multirow{4}{*}{$\begin{array}{l}\text { Stilisasi gerak orang saling } \\
\text { menverang } \\
\text { Stilisasi gerak orang membalikan } \\
\text { badan } \\
\text { Stilisasi gerak orang melihat } \\
\text { denganiarak dekat } \\
\text { Stilisasi gerak orang berperang } \\
\end{array}$} \\
\hline 17. & & Ngglebak & & \\
\hline 18. & & Linglingan & & \\
\hline 19. & & Perangan 3 & & \\
\hline 20. & & Penekan & & Stilisasi gerak orang memanjat \\
\hline 21. & & Menendang & & \multirow{3}{*}{\begin{tabular}{|l|} 
Stilisasi gerak orangmenendang \\
Stilisasi gerakkaki burung prenjak \\
Stilisasi gerak orang melihat \\
\end{tabular}} \\
\hline 22. & & Prenjak tinaji & & \\
\hline 23. & & Nginguk & & \\
\hline 24. & & Perangan 4 & & \multirow{2}{*}{\begin{tabular}{|l|} 
Stilisasi gerak orang berperang \\
Stilisasi gerak orang mengejar \\
\end{tabular}} \\
\hline 25. & & Mengejar & & \\
\hline 26. & & Mundur & & \multirow{4}{*}{$\begin{array}{l}\text { Stilisasi gerak orang berjalan } \\
\text { mundur } \\
\begin{array}{l}\text { Stilisasi gerak orang mengankat kaki } \\
\text { kiri }\end{array} \\
\text { Stilisasi gerak orang berguling ke } \\
\text { arah depan } \\
\text { Stilisasi gerak orang meloncat }\end{array}$} \\
\hline 27. & & Junjungan kiri & & \\
\hline 28. & & Berguling ke depan & & \\
\hline 39. & & Loncat & & \\
\hline 30. & & Perangan 5 & & Stilisasi gerak orang berperang \\
\hline
\end{tabular}


Tabel 17. Jenis-jenis gerak presentatif tokoh Cakil pada perang

\begin{tabular}{|c|c|c|c|c|}
\hline \multicolumn{2}{|c|}{ Adegan } & Nama tokoh & \multirow{2}{*}{ Jenis gerak } & \multirow{2}{*}{$\begin{array}{c}\text { Keteran } \\
\text { gan }\end{array}$} \\
\hline No. & \multirow{12}{*}{ Perang } & Cakil & & \\
\hline 1. & & Tanjak & \multirow{11}{*}{ Presentatif } & Kesan gagah \\
\hline 2. & & Tanjak & & Kesan gagah \\
\hline 3. & & Ngelit & & Kesan mengintai \\
\hline 4. & & Tanjak & & Kesan gagah \\
\hline 5. & & Capengan & & Gerak penghubung/sekaran tari \\
\hline 6. & & Cekotan & & Kesan ngglece \\
\hline 7. & & Tanjak & & Kesan gagah \\
\hline 8. & & Balangan & & Kesan siaga \\
\hline 9. & & Ngelit & & Kesan mengintai \\
\hline 10. & & Tanjak & & Kesan gagah \\
\hline 11. & & Glebakan & & Kesan waspada \\
\hline
\end{tabular}

Tabel 18. Jenis-jenis gerak representatif tokoh Cakil pada perang

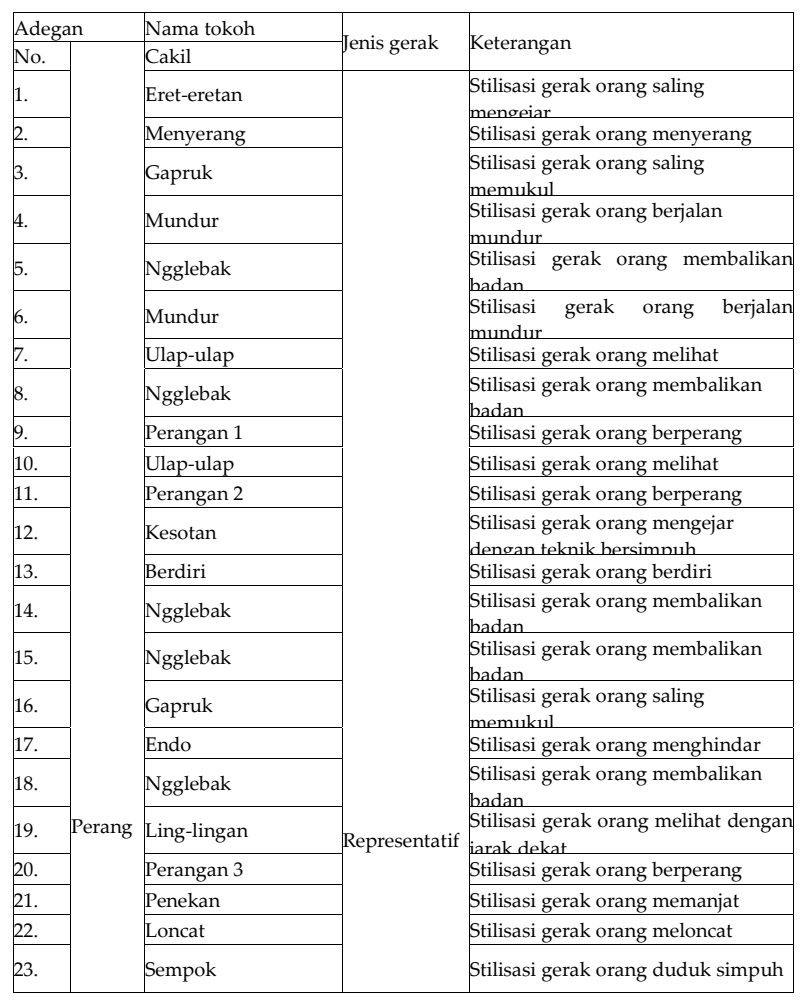

Tabel 19. Jenis-jenis gerak presentatif tokoh Anoman pada mundur beksan

\begin{tabular}{|l|l|l|l|l|}
\hline \multicolumn{2}{|c|}{ Adegan } & \multicolumn{1}{|c|}{ Nama tokoh } & Jenis gerak & Keterangan \\
\hline No. & $\begin{array}{l}\text { Mundur } \\
\text { beksan }\end{array}$ & Anoman & Presentati & Kesan gagah \\
\hline 1. & & Tanjak & \\
\hline
\end{tabular}

Tabel 20. Jenis-jenis gerak representatif tokoh Anoman pada mundur beksan

\begin{tabular}{|l|l|l|l|l|}
\hline \multicolumn{2}{|l|}{ Adegan } & Nama tokoh & \multirow{2}{*}{} & \\
\hline No. & $\begin{array}{l}\text { Mundu } \\
\text { beksan }\end{array}$ & Anoman & Jenis gerak & Keterangan \\
\hline 1. & & Srimpet & Representatif & $\begin{array}{l}\text { Stilisasi gerak orang berpindah } \\
\text { tembat }\end{array}$ \\
\hline 2. & & Lompat menjangan & Representatif & Stilisasi gerak rusa berlari \\
\hline
\end{tabular}

Tabel 21. Jenis-jenis gerak representatif tokoh Cakil pada mundur beksan

\begin{tabular}{|l|l|l|l|l|}
\hline \multicolumn{2}{|l|}{ Adegan } & Nama tokoh & Jenis gerak & Keterangan \\
\hline No. & $\begin{array}{l}\text { Mundu } \\
\mathrm{r} \\
\text { beksan }\end{array}$ & Cakil & Representatif & Stiisasi gerak orang berjalan mundur \\
\hline 1. & & Mundur & Representatif & Stilisasi gerak rusa berlari \\
\hline 2. & & Loncat menjangan &
\end{tabular}

Tabel 22. Rekapitulasi gerak presentatif Tari Anoman Cakil

\begin{tabular}{|c|c|c|c|c|}
\hline No & Adegan & Nama tokoh & Jenis gerak & Jumlah vokabuler \\
\hline \multirow{2}{*}{1.} & \multirow{2}{*}{ Ada-ada } & Anoman & \multirow{10}{*}{ Presentatif } & 6 \\
\hline & & Cakil & & 5 \\
\hline \multirow{2}{*}{2.} & \multirow{2}{*}{ Maju beksan } & Anoman & & 10 \\
\hline & & Cakil & & 10 \\
\hline \multirow{2}{*}{3.} & \multirow{2}{*}{ Beksan } & Anoman & & 13 \\
\hline & & Cakil & & 20 \\
\hline \multirow{2}{*}{4.} & \multirow{2}{*}{ Perangan } & Anoman & & 4 \\
\hline & & Cakil & & 11 \\
\hline \multirow{2}{*}{5.} & \multirow{2}{*}{ Mundur beksan } & Anoman & & 1 \\
\hline & & Cakil & & 0 \\
\hline 6. & Jumlah total & & & 80 \\
\hline
\end{tabular}

Tabel 23. Rekapitulasi gerak representatif

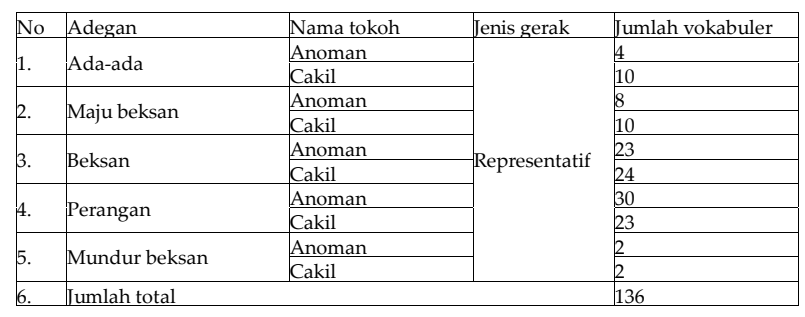

Tabel 24. Presentase gerak presentatif dan representatif

\begin{tabular}{|l|lc|l|l|}
\hline No & Adegan & Tenis gerak & Iumlah \\
\hline 1. & $\begin{array}{l}\text { Ada-ada, maju beksan, beksan, perang, } \\
\text { mundur beksan }\end{array}$ & Presentatif & 80 \\
\hline 2. & $\begin{array}{l}\text { Ada-ada, maju beksan, beksan, perang, } \\
\text { mundur beksan }\end{array}$ & Representatif & 136 \\
\hline 3. & Jumlah total gerak presentatif dan representatif $=34+58$ & 216 \\
\hline 4. & Jumlah presentase gerak presentatif $80: 216 \times 100$ & $37,0 \%$ \\
\hline 5. & Jumlah presentase gerak representatif $136: 216 \times 100$ & $62,9 \%$ \\
\hline
\end{tabular}


Tari yang didominasi gerak-gerak representatif atau gerak penghadir akan mudah dipahami maksudnya oleh penonton. Tari Anoman Cakil termasuk tari yang mudah ditangkap atau dipahami maksudnya oleh penonton, dimana tari tersebut menggambarkan peperangan yang terjadi antara Anoman dan Cakil. Selain gerak representatif, terdapat juga gerak presentatif atau gerak murni yang sematamata untuk kebutuhan ekspresi (Maryono, 2015:55).

\section{Ekspresi wajah/polatan}

Ekspresi wajah / polatan merupakan perubahan kondisi visual raut muka atau wajah seseorang. Ekspresi wajah merupakan sarana untuk mendapatkan pemahaman dah gambaran psikologi seseorang (Maryono, 2010: 56). Anoman merupakan sosok kesatria sehingga memiliki ekspresi dan pembawaan yang tenang berwibawa atau anteb, tegang, lincah dan terdapat unsur ngglece. Sedangkan Cakil memiliki ekspresi dan pembawaan yang congkak atau kemaki dan terkesan ngglece.

\section{Pola Lantai}

Pola lanti merupakan garis yang dibentuk dari gerak tubuh penari yang terlintas pada lantai. Beragam jenis garis yang dibentuk penari pada lantai atau panggung pertunjukan merupakan garis imajiner yang dapat ditangkap dengan kepekaan rasa. Pola lantai terdiri dari dua bentuk yaitu garis lurus dan garis lengkung. Garis lurus memiliki kesan kuat dan sederhana, sedangkan garis lengkung memiliki kesan lembut (Maryono, 2010: 5759).
Bentuk pola lantai Tari Anoman Cakil secara garis besar menggunakan garis-garis lurus. Menurut sifatnya, garis lurus memiliki kesan kuat dan tegas. Hal ini sangat tepat, karena pada dasarnya Tari Anoman Cakil merupakan penggambaran anoman yang sedang berperang melawan raksasa yaitu Cakil, dimana garis-garis lurus ini lebih tepat karena lebih memperlihatkan suasana kekokohan dan kebijakan.

\section{Rias}

Rias Tari Anoman Cakil yaitu menggunakan rias peran dengan rias karakter khusus. Rias Anoman menggunakan rias karakter kera dan rias Cakil menggunakan rias karakter prengesan khusus Cakil. Rias yang digunakan oleh kedua tokoh berbahan dasar singuid dengan warna dasar yaitu putih, hitam dan merah. Anoman yang dominan menggunakan warna putih dan Cakil menggunakan warna merah, warna hitam dijadikan sebagai garis tegas pada wajah.

\section{Busana}

Bentuk kesenian yang berakar dari cerita Mahabarata maupun Ramayana yang merupakan personifikasi dari wayang kulit yang terdekat adalah bentuk wayang orang. Dalam hal ini karya Tari Anoman Cakil susunan Didik Bambang Wahyudi lebih ditekankan pada personifikasi wayang orang. Anoman menggunakan busana antaralain: bagian kepala Irah- irahan gelung minangkara warna putih, sumping nagamangsa, dan Cangkeman kera warna putih. Bagian badan: Simbar dodo bulu putih, kalung kace mote hitam, klat bahu nagamangsa, gelang poles, sabuk, epek 
timang, sampurgendhologiriwarna putih, uncal, bara samir, dan tubuh dilabur singuid warna putih. Bagian bawah: jarik poleng bentuk supit urang, celana bludru warna hitam, dan binggel. Busana yang digunakan Cakil bagian kepala yaitu irah-irahan keling walik, udhal-udhalan, cangkeman, dan sumping nagamangsa. Bagian badan yaitu kalung kace, srempang, kelat bahu nagamangsa, sabuk, poles, epek timang, boro samir, uncal, dan sampur. Bagian bawah menggunakan jarik supit urang, binggel, lancingan, dan Keris sebagai properti.

\section{Musik}

Pada pertunjukan tari-tarian tradisional musik memegang peranan sangat penting yakni sebagai: a) penunjuk isi, b) ilutrasi / nglambari, c) membungkus / mungkus, d) menyatu / nyawiji (Maryono, 2010). Musik tari padatari Anoman Cakil yaitu: maju beksan diawali dengan Adaada laras slendro manyuro lalu dilanjutkan Lancaran Wrahatbala slendro manyuro, beksan Ladrang Agun-agun laras slendro manyuro dan diakhiri dengan Lancaran Anakil laras slendro Manyuro kemudian Lancaran Anakil laras slendro manyuro teknik balungan mlaku. Perangan dengan garap gendhing Lancaran Anakil laras slendro manyuro teknik balungan mlaku Selanjutnya garap gendhing Sampak laras slendro pathet manyuro. Mundur beksan garap gendhing Sampak laras slendro pathet manyuro.

\section{Panggung}

Panggung merupakan tempat atau lokasi yang digunakan untuk menyajikan suatu tarian (Maryono, 2015: 66). Pertunjukan Tari Anoman Cakil pada awalnya dipentaskan di pendhopo, seiring dengan perkembangan, Tari Anoman Cakil pada dasarnya sifatnya dapat dipentaskan di panggung manapun, tergantung dari event itu sendiri menghendaki untuk melakukan pertunjukan di panggung yang dikehendaki.

\section{Properti}

Properti tari adalah sebuah alat yang digunakan sebagai pendukung dan perlengkapan sebuah pertunjukan tari. Penggunaan properti dalam tari bertujuan untuk menambah nilai estetika tarian yang ditampilkan. Properti juga difungsikan sebagai senjata dan media ekspresi dalam sebuah tarian. Maryono berpendapat bahwa:

Kehadiran keris dalam seni pertunjukan memiliki fungsi yang erat hubunganya dengan sistem penokohan dalam rangka memperkuat, mencirikan dan mempresentasikan karakteristik figur sebagai tokoh. Kedudukan keris dalam seni pertunjukan tradisi kita dapat difungsikan: 1) sebagai alat atau properti, 2) sebagai identitas tokoh, 3) sebagai kelengkapan busana, dan 4) sebagai simbol kekuasaan dan sumber kekuatan" (Maryono, 2012:130).

Sesuai dengan pernyataan tersebut, Tari Anoman Cakil menggunakan keris sebagai alat atau properti yang dibawa oleh Cakil untuk memerangi Anoman, tetapi ternyata Cakil mati dengan Kerisnya sendiri dan peperangan dimenangkan oleh Anoman. Keris juga digunakan sebagai identitas tokoh, penggunaan keris pada tokoh Cakil yaitu dipasang secara terbalik.

\section{KREATIVITAS DIDIK BAMBANG WAHYUDI}

Kreativitas merupakan usaha seseorang mencipta atau daya cipta. Utami 
Munandar menyatakan kreativitas adalah umum untuk menciptakan sesuatu yang baru, atau memberi gagasan-gagasan baru yang dapat diterapkan dalam pemecahan masalah, juga sebagai kemampuan untuk melihat hubungan-hubungan baru antara unsur-unsur yang sudah ada sebelumnya. Hal tersebut berarti sebuah kemampuan untuk membuat kombinasi baru, berdasarkan data, informasi atau unsurunsur yang ada (1999: 28- 33).

Mendeskripsikan mengenai kreativitas Didik Bambang Wahyudi dalam karya Tari Anoman Cakil, Utami Munandar mengutip pendapat Rhodes dalam bukunya yang berjudul Kreativitas dan Keberbakatan yang menyatakan bahwa pada umumnya kreativitas dirumuskan dalam istilah person, press, proscess, dan product (Munandar, 1999: 26-29).

\section{Person}

Person atau pribadi merupakan peran penting yang mampu menumbuhkan ide kreativitas dalam diri sendiri atau perseorangan karena melalui pribadi mampu menumbuhkan ide kreatif yang baru dengan adanya dukungan dari lingkungan sekitar (Munandar, 1999:26).

Didik Bambang Wahyudi sebagai pribadi, dalam hal ini koreografer sangat dipengaruhi oleh bakat, pengalaman, dan lingkungan budayanya. Pribadi Didik Bambang Wahyudi memiliki kemampuan dalam mencipta dan menyususn karya tari. Pengembangan pribadi Didik Bambang Wahyudi sebagai koreografer dapat dilihat dari karya-karya tarinya. Hal ini sangat erat kaitanya dengan pengalaman sebagai penari.

Menurut Daryono, sebagai rekan dosen dan rekan seniman paham mengenai karakter geraknya, memang ia spesial pada gerak-gerak dan karakter Cakil, kemudian tidak menutup kemungkinan karna tebalnya karakter tersebut juga didalamnya terdapat keterampilan yang semacamnya yaitu kera dan itu menjadi kekuatan utama sebagai seorang koreografer dalam menyusun sebuah karya tari terutama untuk gagahan(Daryono, wawancara 11 Desember 2019).

Daryono mengatakan bahwa Didik Bambang Wahyudi sebagai seorang koreografer sangatlah sensitif terhadap gagasan suatu karya, alur pikiran dan sebagainya, yang pada akhirnya mengrucut pada visualisasi bentuk garap. Koreografer sangat menjaga hal tersebut, kesadaran akan sebuah maksud, rasa, isi, ungkapan yang tertuang di dalam bentuk garap sangat disiplin, tidak ada yang terkesan asal-asalan. Hal-hal itu ia sangat disiplin dan sangat kuat. Didik Bambang Wahyudi juga selalu mencoba untuk tidak selalu nyaman di dalam kebiasaan seperti Cakil yang sudah ada, melainkan terdapat inovasi-inovasi yang selalu dikembangkan (Daryono, wawancara 11 Desember 2019).

Pengalaman Didik Bambang Wahyudi terhadap kreativitas penciptaan Tari Anoman Cakiltidak terlepas pada kemampuanya terhadap karakter-karakter khusus. Ketertarikannya pada karakter khusus karena adanya kesadaran diri mengenai karakter atau kualitas ketubuhan yang dimiliki yaitu dengan postur tubuh yang kecil dan ramping dirasa cocok pada karakter seperti Cakil dan kera. Karakter tersebut membutuhkan gerak yang lincah. Didik Bambang wahyudi merasa mampu dan mulai menekuninya. Selain itu terdapat tantangan-tantangan pada karakter tersebut 
berupa keterampilan yang lebih. Tidak sekedar terampil, melainkan juga bagaimana mendalami ekspresi pada karakter tersebut. teknik gerak dan karakter khusus dari sisi tuntutan kualitas ketubuhannya memang membutuhkan keahlian khusus untuk memerankan tokoh seperti Cakil dan Kera. Hal tersebut yang membuat Didik Bambang Wahyudi mulai mendalami karakter khusus yang sesuai.

\section{Press}

Pendorong atau motivasi adalah faktor penting yang turut dalam menciptakan suatu karya. Pendorong atau motivasi dalam melakukan sebuah kreativitas menurut Utami Munandar terdapat dua faktor yaitu faktor internal dan faktor eksternal (1999:28). Faktor-faktor tersebut adalah sebagai berikut: (1) faktor internal: Faktor internal yang dimiliki Didik Bambang Wahyudi sebagai seorang koreografer pada Tari Anoman Cakil yaitu didasarkan pada keinginan menggarap dua tokoh yang memiliki karakter yang berbeda tetapi memiliki gerak kaki yang sama yaitu trincing. Menurut Daryono, dalam memunculkan karya tari tersebut, koreografer dipengaruhi dengan faktor internal yang didasari dengan pengalaman Didik Bambang Wahyudi sebagai seorang figur seniman yang memiliki kemampuan baik sebagai penari atau pun mencipta tari. Koreografer sudah dikenal sebagai penata tari Gagah Gaya Surakarta yang spesialisnya ada pada karakter khusus yaitu karakter Cakilan dan Kethekan yang cenderung bermain diwilayah lincah dan terampil. Dengan ini lahirlah sebuah karya yang lekat dengan teknik-teknik tersebut seperti halnya karya Tari Anoman Cakil ini (Daryono, wawancara
11 Desember 2019). (2) eksternal: Faktor eksternal yang mempengaruhi Didik Bambang Wahyudi dalam karya Tari Anoman Cakil yaitu untuk memenuhi kebutuhan tugas akhir minat kepenarian di STSI atau sekarang lebih dikenal dengan Institut Seni Indonesia Surakarta atau ISI Surakarta (Didik Bambang Wahyudi, wawancara 17 Oktober 2019). Ide materi Tari Anoman Cakil pada saat itu bermula dari Sunarno Purwolelono sebagai ketua jurusan waktu itu yang memikirkan materi cakilan dan kethekan sebagai materi Ujian Tugas Akhir Karyono.

\section{Process}

Proses merupakan bagian yang sangat penting dalam menciptakan sebuah karya tari. Dalam mengawali sebuah proses harus bisa membuat sebuah karya tari berdasarkan pengalaman atas apa yang dilihat sehingga dari melihat tersebut muncul sebuah ide-ide baru yang kreatif (Soedarsono: 1978: 38). Proses penciptaan tari Anoman Cakil memalui beberapa tahap yaitu koreografer memulai dari merasakan dan berimajinasi tentang tokoh Anoman dan Cakil, kemudian melakukan eksplorasi yang cukup ekstra. Proses penyususnan Tari Anoman Cakil dilakukan dengan Pamardi, dimana Pamardi berperan sebagai Anoman dan Didik Bambang Wahyudi berperan sebagai Cakil, sehingga koreografi pada tari tersebut divisualisasikan pertemuan antara dua karakter yang sama- sama kuat dan tidak mau kalah, meskipun pada akhirnya pertarungan dimenangkan oleh Anoman, tetapi kekalahan Cakil tidak wujudkan secara tragis (Didik Bambang Wahyudi, Wawancara 17 Oktober 2019). 


\section{Product}

Product atau produk adalah hasil akhir dari proses kreatif. Produk yang dihasilkan oleh Didik Bambang Wahyudi dalam hal ini yaitu karya tari Anoman Cakil. Produk kreatif adalah hasil akhir dari kreativitas yang didalamnya terdapat unsur orisinalitas dan kebaruan dalam karya tersebut (Munandar, 1999:28). Membahas produk kreativitas Didik Bambang Wahyudi dalam karya Tari Anoman Cakil, mengingat bahwa produk merupakan hasil akhir dari proses kreativitas seorang koreografer yang didalamnya terdapat unsur kebaruan, maka hal tersebut diperkuat menggunakan konsep Srihadi yaitu APIK. APIK yang berarti art, performance, inovatif dan komunikatif. Karya seni yang berbobot harus mempertimbangkan beberapa unsur terkait yakni: rasa keindahan atau art, sajian atau penampilan yang menarik, memiliki kebaruan atau inovasi, dan dapat menyampaikan pesan yang mampu diterima oleh masyarakat pendukungnya sehingga terjadi interaksi timbal balik atau komunikatif (Srihadi, 2013:108).

\section{ART}

Art atau keindahan merupakan pengertian seni yang telah diwariskan oleh bangsa Yunani. Pada Tari Anoman Cakil selama esensialnya menggunakan medium tradisi yang dikembangkan sangat tepat menggunakan konsep APIK yang dalam artian art di dalam konsep gerak, rias busana, pola lantai, musik iringan masih menggunakan elemen-elemen tradisi yang dikembangkan, hal tersebut seiring dengan konsep APIK yang dikemukakan oleh Srihadi dalam hal ini pada art atau esensi keindahanya (Srihadi, wawancara 18
November 2019). Karya tari merupakan cabang dari seni, keindahan dari sebuah karya tari dapat dirasakan melalui karya tersebut. Melalui imajinasi dan kepekaan rasa, penonton atau penghayat dapat merasakan sebuah keindahan yang ada dalam karya tersebut. Imajinasi tersebut dibentuk melalui medium ungkap karya tari, yang merupakan daya pacu dari seniman untuk menyampaikan sebuah nilai yang terkandung dalam karya tersebut.

Menurut The Liang Gie sebuah karya seni sebagai ciptaan manusia mempunyai nilai estetik atau nilai keindahan. Nilai estetik karya seni dapat dirasakan melalui nilai bentuk dan nilai kehidupan diluar seni yang dapat danmampu diungkap melalui sebuah karya seni. Nilai bentuk dapat dirasakan melalui pengamatan inderawi atau sesuatu yang dapat dinikmati dengan indera yang dimiliki oleh penghayat. Nilai kehidupan adalah nilai-nilai dari kehidupan di luar seni yang diteruskan sebagai isi melalui medium ungkap yang digunakan (Gie, 1976: 70-71). Dalam hal ini peneliti mengungkap nilai bentuk yang terdapat dalam Tari Anoman Cakil. Suatu lambang dapat digunakan sebagai tanda untuk memaknai suatu bentuk. Menurut De Witt $H$ Parker yang diterjemahkan oleh SD Humardani dalam bukunya yang berjudul Dasar-Dasar Estetika yaitu:

Simbolis adalah fungsi untuk melambangi benda peristiwa atau universal. Warna garis, dan bentuk lukisan pemandangan alam dapat menarik dan memikat manusia bukan hanya karena sebagai warna, garis dan bentuk saja, melainkan juga merupakan lambanglambang dari pohon, awan, bukit, rumah, 
sawah, ladang, air sungai, matahari dan lainnya (1980:77).

\section{a. Makna Simbolis Rias dalam Karya Tari Anoman Cakil}

Karakter peran atau tokoh dalam sebuah seni pertunjukan tari banyak dibentuk dari rias. Rias dalam seni pertunjukan tidak sekedar untuk mempercantik dan memprindah diri tetapi merupakan kebutuhan ekspresi peran sehingga bentuknya sangat beragam tergantung peran yang dikehendaki.

Prinsip dasar merias dalam pertunjukan tari adalah untuk mengubah wajah pribadi dengan alat-alat kosmetik yang disesuaikan dengan karakter peran supaya tampil ekpresif (Maryono, 2015:61). Rias dalam Tari Anoman Cakil sesuai dengan pendapat tersebut, dimana rias yang digunakan oleh kedua tokoh merupakan rias karakter khusus yang sangat menunjang ekspresi.

Warna-warna dasar busana dalam seni pertunjukan mempunyai makna simbolis yang dapat mengarahkan pada pemahaman karakteristik peran atau figur tokoh (Maryono, 2015:15). Warna putih pada Anoman melambangkan sebuah kesucian, kesakralan, kebaikan, spiritual dan kesetiaan. Warna merah pada Cakil melambangkan keangkaramurkaan, kemarahan, kelicikan, kecongkakan, berani, agresif, dan dinamis.

\section{b. Makna Simbolis Busana dalam Karya Tari Anoman Cakil}

Anoman merupakan simbol dari perwujudan manusia kera berwarna putih. Anoman merupakan salah satu keturunan BetharaBayu, dimana kostum yang digunakan oleh Anoman memiliki simbol- simbol sebagai tokoh kera dan penanda bahwa Anoman merupakan keturunan dari Bathara Bayu. Beberapa bagian yang dikenakan oleh Anoman yang memiliki simbol bahwa ia merupakan keturunan dari BetharaBayu diantaranya: irah- irahan, sumping, gelang poles, klat bahu, jarit dan penggunaan sampur. Irah-irahan, dalam karakter Anoman menggunakan irah-irahan khusus yaitu irah-irahan gelung minangkara warna putih. Gelung minangkara cinanderenggo yaitu cendhek ngarep duwur mburi pupuk emas jarot ing asem yang berarti penutup kepala bagian belakang berbentuk udang pada bagian depan rendah dan bagian belakang lebih tinggi. Pupuk emas jarot ing asem merupakan ciri bahwa Anoman merupakan salah satu keturunan dari Bathara Bayu (Suyanto, wawancara 13 November 2019).

Tokoh Cakil merupakan simbol bahwa dalam kehidupan ada manusia-manusia yang posisinya sebagai pengganggu atau penghalang, simbol tersebut berupa nafsu sehingga diwujudnya sebagai tokoh yang berupa Cakil (Wahyu Santoso Prabowo, wawancara 12 Desember 2019). Rias busana Cakil secara keseluruhan melambangkan sosok raksasa dan menakutkan. Tokoh Cakil yang terdapat dalam Tari Anoman Cakil merupakan sosok prajurit dari Negara Alengka, dimana busana yang digunakan memiliki simbol sebagai sosok prajurit dari Kerajaan Alengka.

\section{c. Makna Simbolis Properti dalam Tari Anoman Cakil \\ Bentuk-bentuk properti yang} difungsikan sebagai sarana simbolik tari adalah properti yang memiliki makna yang didalamnya berkaitan dengan peran tari 
(Maryono, 2015:68). Keris digunakan oleh Cakil untuk memerangi Anoman, pada sajian ini keris merupakan sebuah simbol bahwa kekuatan Cakil tidak sebanding dengan kekuatan yang dimiliki oleh Anoman, sehingga Cakil harus membawa keris supaya kekuatan yang dimiliki terkesan seimbang (Didik Bambang Wahyudi, wawancara 17 Oktober 2019).

Penggunaan keris pada Cakil yaitu digunakan secara terbalik atau kewal. Penggunaan keris secara terbalik atau kewal tidak hanya digunakan oleh tokoh Cakil, melainkan terdapat tokoh lain yaitu Setyaki, Ugra Sena saat muda dan Aswa Tama. Penggunaan keris tersebut merupakan salah satu simbol identitas Cakil (Wahyu Santoso Prabowo, wawancara 13 Maret 2020).

\section{PERFORMANCE}

Garap pola lantai, garap level, kemudian garap kekinian yang hubunganya dengan penampilan yang kekinian sangat tepat menggunakan konsep Srihadi yaitu APIK dalam medium performance atau penampilan (Srihadi, wawancaea 18 November 2019). Tari hadir sebagai sebuah karya seni ketika susunan atau koreografi disajikan melalui tubuh seorang penari. Terkait dengan hal itu, koreografer menyatakan bahwa penari mempunyai peran yang sangat penting, penari melalui gerak yang ditampilkan mempunyai untuk menyampaikan pesan, ide ataugagasan yang selanjutnya diharapkan dapat ditangkap oleh penonton. Melihat besarnya peran penari dalam kehidupan tari, maka seorang seniman harus memilki bekal yang cukup yaitu: 1) penari harus kaya akan teknik, 2) Penari harus kaya akan irama, 3) Penari harus kaya akan rasa yaitu kepekaan dan 4) penari harus mampu menginterpretasi tari yang akan disajikan (Dididk Bambang Wahyudi, 20 November 2019).

\section{INOVASI}

Inovasi atau kebaruan merupakan sebuah usaha mengembangkan sesuatu yang sudah ada menjadi hal yang baru. Segala pembaruan yang terdapat didalam sebuah karya sangat tepat menggunakan konsep Srihadi yaitu APIK yaitu inovasi. Inovasi yang dilakukan oleh Didik dalam karya Tari Anoman Cakil yaitu terdapat pada konsep, gerak dan penerapan gerak yogjan atau model sekaran gerak gaya Yogyakarta ke dalam Tari Anoman Cakil.

\section{KOMUNIKATIF}

Pesan yang disampaikan dalam garap Tari Anoman Cakil tersampaikan untuk penonton atau penghayat termasuk dalam elemen komunikatif. Ketika karya tersebut mampu menyampaikan pesan dari tema Tari Anoman Cakil tersebut bebrarti masuk pada elemen Komunikatif (Srihadi, wawancara 18 November 2019). Komunikatif bukan hanya persoalan emosional, melainkan bagaimana penari tersebut mengkomunikasikan nilai atau pesan yang terdapat dalam tari yang disajikan melalui ketubuhan atau penampilan penari sehingga tersampaikan kepada penonton atau penghayat (Wahyu Santoso Prabowo, wawancara 10 Desember 2019). Berdasarkan tanggapan para pakar, penari dan penonton. Dapat ditarik intinya bahwa Tari Anoman Cakil menggambarkan peperangan antara Anoman dan Cakil. Dimana Cakil sebagai penghalang Anoman saat dalam perjalanan ketika mencari Dewi Sinta. 


\section{PENUTUP}

Tari Anoman Cakil disusun oleh Didik Bambang Wahyudi dan S. Pamardi pada tahun 1987. Tari Anoman Cakil merupaka tari gagah gaya Surakarta jenis tari wireng pethilan. Tari ini menceritakan tentang peperangan antara dua tokoh yang memiliki perbedaan karakter yaitu Anoman dan Cakil. Gerak Tari Anoman Cakil lebih dominan pada jenis gerak representatif atau gerak penghadir.

Anoman merupakan sosok kesatria sehingga memiliki ekspresi dan pembawaan yang tenang berwibawa. Sedangkan Cakil memiliki ekspresi dan pembawaan yang congkak atau kemaki dan terkesan ngglece.Bentuk pola lantai Tari Anoman Cakil secara garis besar menggunakan garis-garis lurus. Rias yang digunakan dalam sajian tari ini untuk Anoman adalah rias karakter kera dan Cakil menggunakan rias karakter jenis prengesan khusus Cakil, serta menggunakan busana layaknya wayang orang.Musik tari pada tari Anoman Cakil yaitu menggunakan gamelan jawa lengkap. Tari Anoman Cakil pada dasarnya sifatnya dapat dipentaskan di panggung manapun, tergantung dari even itu sendiri menghendaki untuk melakukan pertunjukan di panggung yang dikehendaki.Tari Anoman Cakil menggunakan keris sebagai alat atau properti yang dibawa oleh Cakil untuk memerangi Anoman.

Kreativitas Didik Bambang Wahyudi dalam karya Tari Anoman Cakil didasari pada karya yang disusun guna memenuhi materi pembelajaran dan ujian tugas akhir minat kepenarian di STSI Surakarta atau Institut Seni Indonesia (ISI) Surakarta. Tari Anoman Cakil merupakan karya tari yang lahir dari hasil interpretasi
Didik Bambang Wahyudi. Keselarasan antara pribadi dengan proses kreatif, serta kemampuan mengimplementasikan sebuah cerita dimana pada dasarnya Anoman Tidak pernah bertemu dengan Cakil. tetapi bukan tidak mungkin Anoman bertemu Cakil dalam sebuah perjalananya. Kreativitas Didik Bambang Wahyudi pada Tari Anoman Cakil juga tidak terlepas pada unsur pribadi atau pengalaman sebagai faktor yang mempengaruhi terhadap karya tersebut. Terdapat kesadaran koreografer akan estetika atau keindahan bentuk, terdapat pula inovasi atau kebaruan koreografer mengenai konsep dan gerak yang dituangkan pada karya tersebut. Serta mengkomunikasikan karya tersebut melalui unsur-unsur tari yang ada.

\section{DAFTAR PUSTAKA}

Gie, The Liang. 1976. Garis Besar Estetika (Filsafat Keindahan). Yogyakarta: Penerbit Karya.

Haryono, Sutarno. 2010. Kajian Pragmatik Seni Pertunjukan Opera Jawa. Surakrta: Pascasarjana ISI Surakarta bekerja sama dengan ISI Press.

Kartika, Dharsono Sony, Nanag Ganda Prawira. 2004. Pengantar estetika. Bandung: Rekayasa Sains.

Maryono. 2011. Penelitian Kualtatif Seni Pertunjukan. ISI Press Solo. .2015. Analisa Tari. ISI Press Solo.

Munandar, Utami, 1999. Kreativitas dan Keberbakatan, Strategi Mewujudkan Potensi Kreatif dan Bakat. Jakarta: Gramedia Pustaka Utama. 
Pamardi, Silvester, 2017. Teroka Tari Gaya Surakarta. Surakarta: ISI Press.

Parker, Dewitt H. 1979/1980. Dasar- dasar Estetik, ed. Humardani. Surakarta: SUB PROYEK ASKI proyek pengembangan IKI.

Srihadi. 2013. "Wayang Babar Inovasi Wayang Orang". Disertasi S-2 Seni Tari ISI Yogyakarta
Sudjarwo, S. Heru, Sumari, Undung Wiyono. 2010. Rupa \& Karakter Wayang Purwa. Jakarta: Kaki Langit Kencana Prenada Media Group.

Wahyudi, Didik Bambang. 2011. "Perkembangan Tari Cakil Di Surakarta 1970-2010". Tesis S-2 Pengkajian ISI Surakarta. 